\title{
レーザーエネルギー伝送の小型無人飛翔体への応用"1 \\ Laser Energy Transmission to a Small-Unmanned Aerial Vehicle
}

\author{
武 田 和 也 ${ }^{* 2} \cdot$ 河 島 信 樹 ${ }^{* 2} \cdot$ 矢 部 恭 - ${ }^{* 2}$ \\ Kazuya TAKEDA, Nobuki KAWASHIMA and Kyoichi YABE
}

Key Words: Diode Laser, Energy Transmission, Unmanned Aerial Vehicle, Airplane, Helicopter

\begin{abstract}
A laser energy transmission system for a small-unmanned airplane(Kite-plane) has been developed and a long-time flight demonstration was done successfully in Osaka dome stadium (baseball stadium) at an altitude of $50 \mathrm{~m}$. This test flight shows that it can be practically applied for the surveillance flight in natural disaster such as earthquakes, floods etc. In order to increase the horizontal range keeping the low altitude, an application to a helicopter flight is undertaken.
\end{abstract}

\section{1. は じめ に}

我々はこれまでに半導体レーザーと太陽電池を用い たレーザーエネルギー伝送システムによって月極域に あるといわれる水を探査する水探査車を送り込むこと を考えていた ${ }^{1)}$. 月の水については, NASAの月探査機 によって一年中太陽光が届かない月極域のクレーター 底部に大量の水が存在するというデータがもたらされ ている ${ }^{2)}$. しかし，これは直接水分子を観測したわけで はないので, 確実に氷であるというためには探査車によ る直接観測が必要である.このとき探査車は太陽光が得 られないので, 我々が考えたシステムでは, 長期間探査 車を運用するために，半導体レーザーによってクレー ター外縁から底部へエネルギー伝送を行うというもの である.我々はこれまでに, 月水探査車モデルを用いて 長距離エネルギー伝送実験を行っている (第 1 図 $)^{3)}$.

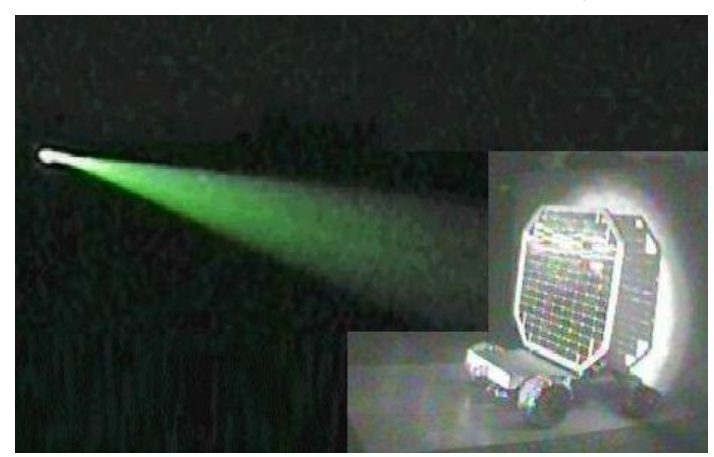

第 1 図 月永探査車モデルへの長距離エネルギー伝送実験

このようなレーザーエネルギー伝送は宇宙空間のみ ではなく地上でもその応用が考えられる.とくに人間が 近づきにくい場所（原子炉事故や自然災害）で長時間活 動する場合はエネルギー源の確保が重要である. そこで,

*1C2008 日本航空宇宙学会

平成 19 年 3 月 12 日, 第 26 回宇宙エネルギーシンポジウムにて講演

平成 19 年 11 月 23 日原稿受理

*2近畿大学リエゾンセンター
地上応用として,レーザーエネルギー伝送のみで飛行す る小型無人飛行機の長時間飛行実証試験システムを作 製し飛行実験を行った.

\section{2. 小型無人飛行機へのエネルギー伝送}

小型無人飛行機に限らず, 飛行機はバッテリーや燃料 の量によって飛行時間が限られる. 長時間飛行するため には外からエネルギーを供給する必要がある.我々は月 水探査車で考えた半導体レーザーと太陽電池によるレ 一ザーエネルギー伝送システムを使用し, 長時間無着陸 飛行を目指すことにした.レーザー光でエネルギーを伝 送して飛行機を飛行させることは，これまでに NASA が幅 $2 \mathrm{~m}$ のプロペラ駆動のラジコン飛行機に太陽電池 を搭載して $1 \mathrm{~kW}$ の赤外線レーザーを照射、手動で追尾 する実験を行っている ${ }^{4)}$. 日本では東工大が紙飛行機に 貼り付けたアルミに水滴をつけてパルス幅 $5 \mathrm{~ns}$ の YAG レーザーを照射することで、瞬間的な水の蒸発の反発力 で飛行させている ${ }^{5)}$. だが我々のような自動追尾による 長時間運用可能なシステムは初めてである.

レーザーエネルギー伝送型小型無人飛行機の利用状 況としては, 災害時の状況把握, 通信網の確保, 緊急時 の携帯電話・放送電波などの中継基地, 資源探査, 環境 観測, 都市部の 24 時間通信中継基地, 防犯モニター, レジャーやホビーでの活用，などを想定している.

\section{3. 長時間飛行実証試験システムの作製}

今回作製したシステムはレーザーエネルギーのみで 飛行し続けることを実証する試験システムであり, 小型 無人飛行機（カイト型飛行機）とレーザーエネルギー伝 送システムから構成されている. 小型無人飛行機はラジ コン飛行機で，地上から手動にて制御を行う。機体には 地上からレーザー光を受ける太陽電池と小型バッテ 
リーを搭載し, 太陽電池の出力によって飛行を維持する. レーザーエネルギー伝送システムは半導体レーザーと 自動追尾装置によって構成されている.

まず小型無人飛行機は小型バッテリーによって上空 一上昇し，旋回運動に入る.太陽電池パネルが小型無人 飛行機の底部に下向きに搭載され, 地上からのレーザー 光を受光し発電を行う.レーザー光を受ける間, 飛行機 は旋回し続けるので, その動きに合わせて自動追尾装置 によってトラッキングを行い, エネルギーを供給し続け る。このエネルギーによって長時間飛行が可能となる.

3.1 小型無人飛行機 小型無人飛行機は機体などの 基本構成の他, 上昇用バッテリーと太陽電池パネルから 構成されているモーター駆動のラジコン飛行機である

(第 1 表)。制御は人が地上からラジコンで行う仕様に なっている. 主翼は布製で凩のような構造であり，折り たたんでコンパクトに持ち運ぶことができる(第 2 図). 機体重量は約 $800 \mathrm{~g}$ であり, 約 $600 \mathrm{~g}$ までの重量を搭載 することができる．実際の飛行ではおよそ風速 $10 \mathrm{~m} / \mathrm{s}$ までの風の中を飛行可能である. 軽量であり低速でも飛 行できることから, 人の手から離陸し, 着陸時は人がキ ヤッチすることができるなど, 飛行場所を選ばない特徴 がある。

第 1 表 小型無人飛行機の概要

\begin{tabular}{ll}
\hline \multicolumn{1}{c}{ 項目 } & \multicolumn{1}{c}{ 仕様 } \\
\hline サイズ & 全長 : $780 \mathrm{~mm}$, 全幅 : $1360 \mathrm{~mm}$, 全高 : $580 \mathrm{~mm}$ \\
翼面積 & $0.5032 \mathrm{~m}^{2}$ \\
重量 & $800 \mathrm{~g}$ \\
飛行高度 & $\sim 500 \mathrm{~m}$ \\
消費電力 & 平均約 $37 \mathrm{~W}$ (安定旋回運動時) \\
手動制御方式 & PCM 方式 RCプロポ $(73 \mathrm{MHz})$ \\
ペイロード & $600 \mathrm{~g}$ (装置電池等含む) \\
搭載 & リチウムポリマー電池 $(7.4 \mathrm{~V}, 480 \mathrm{mAh})$ \\
& モーターアンプ (受信機) \\
& オプションでカメラ等搭載 \\
\hline
\end{tabular}

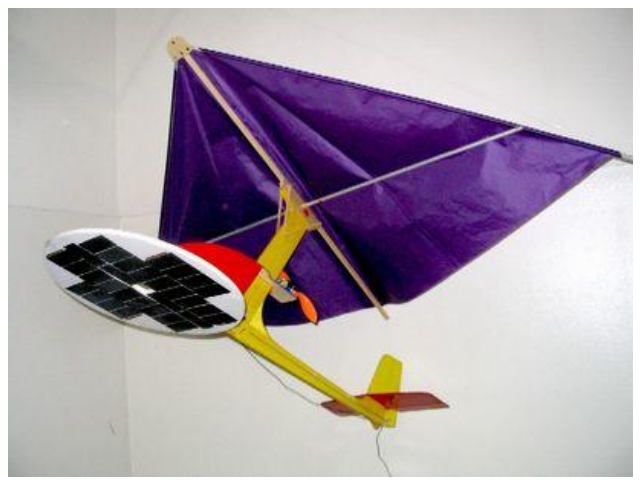

第 2 図 作製した小型無人飛行機

3.2 太陽電池パネル 機体底部には下向きに太陽電 池パネル（第 2 表，第 3 図）が取り付けてある.太陽電 池パネルには Single-Junction GaAs 太陽電池セルが 30 枚
（10 枚直列にしたものを 3 本並列にしている）使用さ れている.この太陽電池セルは人工衛星用に開発された ものであり，太陽光に対する変換効率は $19 \%$ ，太陽光 とほぼ同じ光強度のレーザー光 $\left(808 \mathrm{~nm}, 100 \mathrm{~mW} / \mathrm{cm}^{2}\right)$ に 対しては約 40\%と高効率のものである. 表面に無反射コ 一ティングされたガラス状カバーが貼り付けられてお り，それによって物理的強度が増している。

パネル中央には追尾用のコーナーキューブが取り付 けてある。レーザーが太陽電池パネルに照射された時, コーナーキューブに入射したレーザー光はレーザーエ ネルギー伝送システムに向けて反射する. $\pm 30^{\circ}$ 程度の 機体の傾き（コーナーキューブの傾き）があってもレー ザー射出点に向けて反射可能である。

第 2 表 太陽電池パネルの概要

サイズ 直径 : 約 $330 \mathrm{~mm}$, 厚さ：10 $\mathrm{mm}$

重量 約 $120 \mathrm{~g}$

太陽電池使用, 10 枚直列を 3 並列

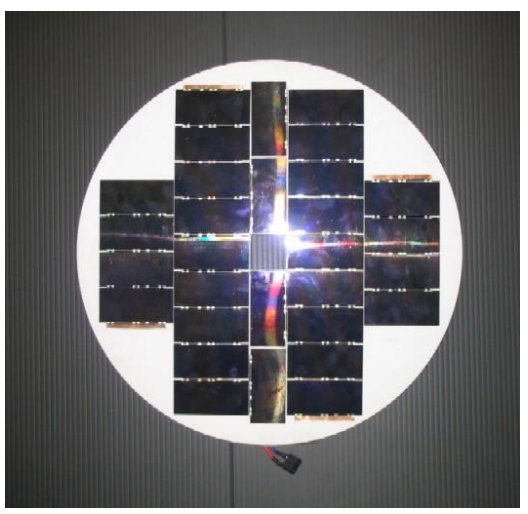

第 3 図 太陽電池パネル

3.3 レーザーシステム 今回エネルギー伝送に使用 しているレーザーは波長 $808 \mathrm{~nm}$, 最大出力 $200 \mathrm{~W} / \mathrm{cw}$ の ファイバーカップリングタイプ高出力半導体レーザー （コア径 $400 \mu \mathrm{m}$ ）（第 3 表）で水冷式と空冷式（第 4 図）の 2 台を同時使用している.

\begin{tabular}{|c|c|}
\hline 波長 & $808 \mathrm{~nm}$ \\
\hline 出力 & $200 \mathrm{~W} / \mathrm{cw}$ \\
\hline ファイバー & コア径 400 ～ $\mathrm{m}$ （NA 0.22） \\
\hline 冷却方式 & 水冷，空冷（ペルチェ冷却） \\
\hline
\end{tabular}

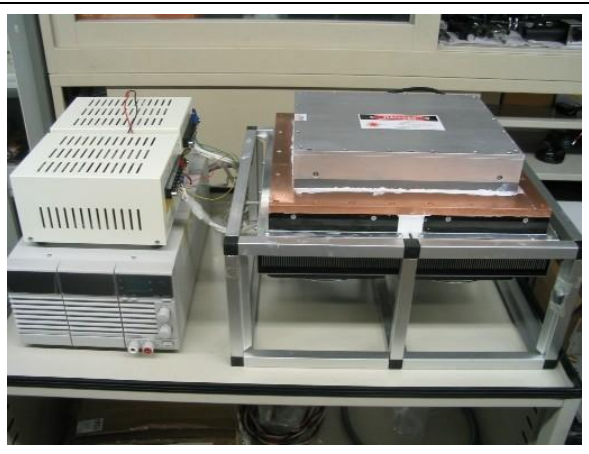

第 4 図 半導体レーザー 
光学系には 2 本のファイバーを取り付ける構造にな っており, 集光スポット径を太陽電池パネルの径にほぼ 合う直径約 $33 \mathrm{~cm}$ とし, 両ファイバーからのレーザー光 がレンズを通って想定飛行高度で光軸が重なるように 光学系を組み上げてある（実際の飛行実験では $50 \mathrm{~m}$ ）.

2 本のファイバーのうち片側のみファイバーの位置 をリニアアクチュエーターで移動することができる。こ のアクチュエーターでファイバー端を前後させること でレーザーの発散角を広げることができる（第 5 図）。 これは小型無人飛行機にレーザーエネルギー伝送を開 始するとき, 旋回飛行している飛行機をキャプチャーす るときに使用する機構である.

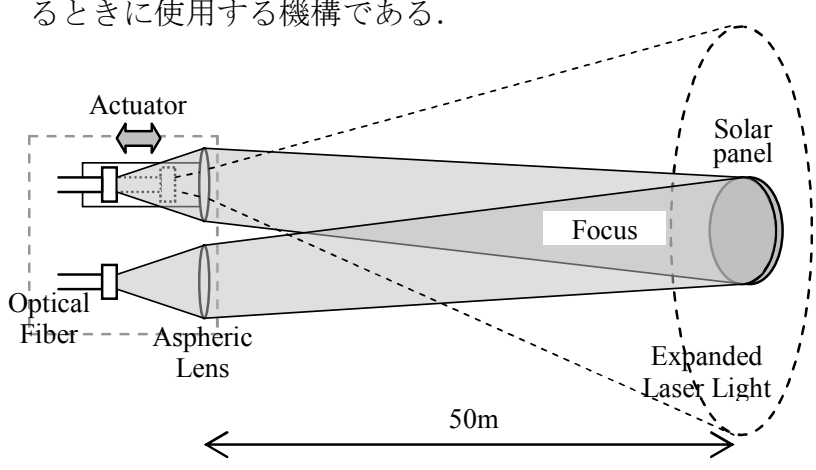

第 5 図 レーザー光の集光と発散

3.4 自動追尾システム 小型無人飛行機へのレーザー エネルギー伝送を行うためには飛行機を追尾しなけれ ばならない. 飛行機の位置を知るため, 太陽電池パネル の中央にあるコーナーキューブから反射したレーザー

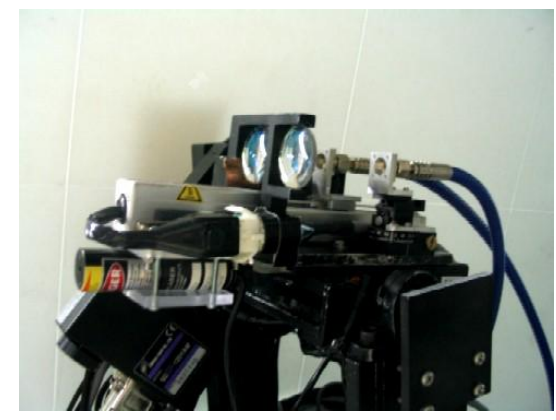

第 6 図自動追尾システム

光を利用するが，コーナーキューブなので反射光は常に レーザー射出点へと反射してくる. 自動追尾システムへ 反射してきた反射光の径はエネルギー伝送用レンズ (直 径 $30 \mathrm{~mm}$ ）よりも大きい（直径約 $50 \mathrm{~mm}$ ). よって直径 $10 \mathrm{~mm}$ の飛行機位置検出用レンズをエネルギー伝送用 レンズと並べて配置してある。これらレンズ群，検出素 子, 及びリニアアクチュエーターはすべて自動追尾シス テムの可動台の上で一体化しており, 自動追尾時には台 ごと動くことになる (第 6 図).

コーナーキューブからの反射光の一部は飛行機位置 検出用レンズを通り, 検出素子である 4 分割フォトダイ オード上に集光する（第 7 図）。飛行機が移動すると検 出素子上の集光点が移動するので, 常に検出素子の中央 に集光点が来るように半導体レーザーの射出方向 (自動
追尾システムの可動台の向き）を制御する.

可動台は小型と大型の 2 つの回転テーブルから構成 されており, 小型回転テーブルがレンズシステムを搭載 し, 大型回転テーブルがそのレンズシステムごと小型回 転テーブルを載せている. 各回転テーブルの回転面は直 交するように配置している.

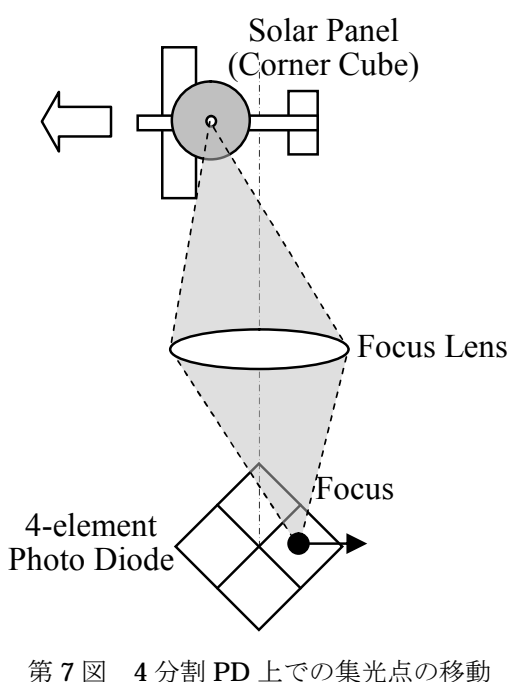

追尾精度は $50 \mathrm{~m}$ 先で $\pm 1 \mathrm{~cm}$ 程度であり，0.2 $\mathrm{rad} / \mathrm{s}$ の 角速度に対応寸る。 $(50 \mathrm{~m}$ 上空を旋回半径 $10 \mathrm{~m}$ で速度 $10 \mathrm{~m} / \mathrm{s}$ の飛行機を追尾可能）

\section{4. 太陽電池パネルの発電実験}

今回使用する太陽電池パネルを小型飛行機に取り付 け, 実験室内にて飛行時の最大電力消費状態であるフル スロットル状態でのパネル出力を計測した (バッテリー 不使用)。レーザーはファイバーから $200 \mathrm{~W}$ を直接照射 し, スポットは太陽電池パネルとほぼ同じ直径 $33 \mathrm{~cm} に$ なっている.このとき飛行機のプロペラによる風を吹き つけ，実際の飛行状態と同じように冷却を行った（パネ ル中央付近で約 $60^{\circ} \mathrm{C}$ ). その結果 $45 \sim 50 \mathrm{~W}$ の出力が得 られた (第 8 図).

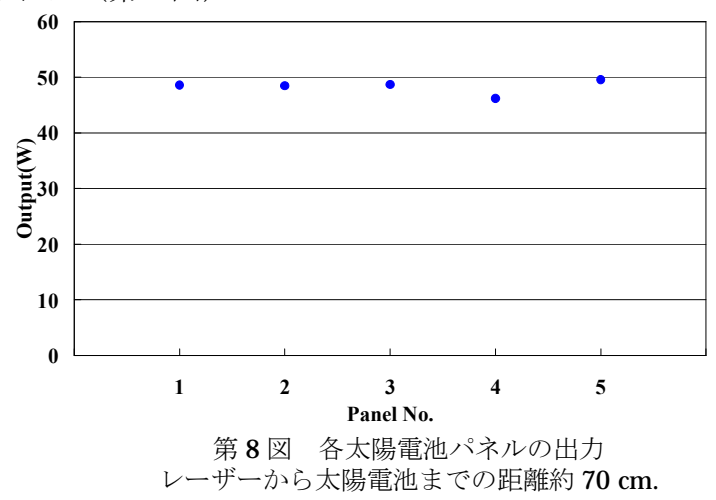

次に我々は実際の試験飛行高度と同じ $50 \mathrm{~m}$ の距離で のレーザー照射発電実験を行った (第 9 図). 図中の Variable Resistor は太陽電池パネルの負荷として可変抵 抗を用い，出力が最大となる最適抵抗值で測定した值， 
Fixed Resister は比較のため飛行機のモーターのインピ ーダンスと同じにした固定抵抗を使ったときの出力,

Kyte Plane は直接飛行機に接続して得られた出力である。 その結果，このシステムではレーザー光は $50 \mathrm{~m}$ 先で多 少発散してしまうが，レーザー出力を $300 \mathrm{~W}$ にすれば $50 \mathrm{~m}$ 離れた太陽電池パネルで $45 \mathrm{~W}$ の出力が見込めるこ とがわかった。

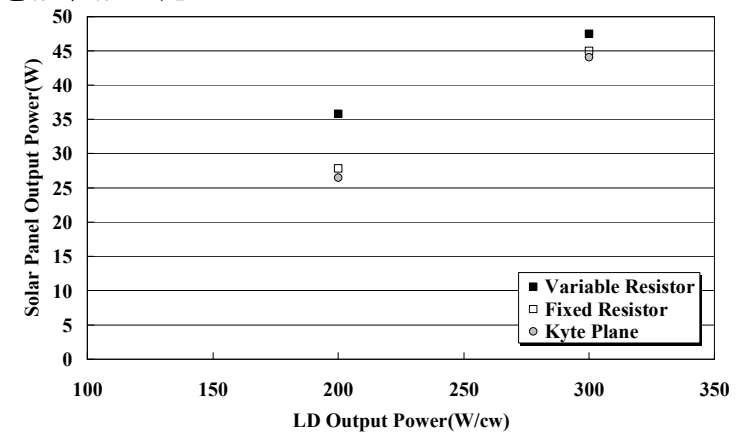

第 9 図 半導体レーザーからの距離 $50 \mathrm{~m}$ での太陽電池パネル出力

\section{5. 小型飛行機の飛行時の消費電力計測}

作製した小型無人飛行機の飛行中の消費電力を計測 するため, 計測装置を搭載して無風時にバッテリーを用 いて屋外で飛行実験を行った（第 4 表）。上昇時にはフ ルスロットル状態となり消費電力は大きくなったが, 旋 回状態では平均して約 $37 \mathrm{~W}$ の電力で飛行することがで きた. $300 \mathrm{~W}$ のレーザーを用いれば小型バッテリーに充 電しながら飛行することができることになる.

第 4 表 小型飛行機の消費電力

\begin{tabular}{|c|c|c|}
\hline 上昇時 & 平均 & 約 $64 \mathrm{~W}$ \\
\hline 旋回飛行（高度一定） & 平均 & 約 $37 \mathrm{~W}$ \\
\hline
\end{tabular}

\section{6. 大阪ドームでのエネルギー伝送飛行実験}

我々は実際に作製した小型無人飛行機・レーザーエネ ルギー伝送システム・自動追尾装置等を使用して大阪ド ームを借りきり, 実際にレーザーによるエネルギー供給 のみで飛行させる実験を行った ${ }^{6)}$.

大阪ドームは天候に左右されず, 高出力レーザーを使 用するという点で安全性を確保しやすい場所である.ま た, 天井まで $60 \mathrm{~m}$ という高さがあり, 実験には十分な 飛行高度を確保することができる.

6.1 自動追尾までのシーケンス レーザーによるエ ネルギー伝送は小型無人飛行機が上空で旋回運動して いるときに開始する.上空までは搭載している小型バッ テリーを使って上昇・旋回運動を行いレーザー照射を待 つ(第 10 図)、レーザーシステムは，前述のリニアアク チュエーターでレーザーの発散角を広げ $(50 \mathrm{~m}$ 上空で 直径約 $10 \mathrm{~m}$ ), 広げたレーザー光の中を小型無人飛行機 が通過するのを待ち構える. 小型無人飛行機がレーザー 光の中を通過したとき反射光を捕らえ, 自動追尾を開始 することになる.自動追尾が開始されてから発散角を絞
り, 太陽電池パネルとほぼ同じ径にする(集光径約 $33 \mathrm{~cm}$ ). この一連の動作が自動化されており, スムーズな運用が 可能となっている.

Expanded Laser Light

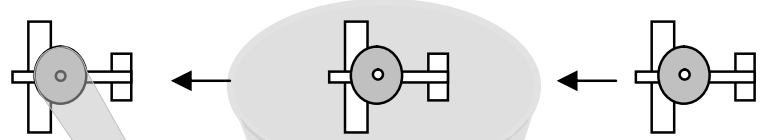

Focus

Tracking

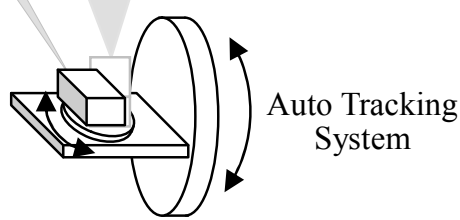

第 10 図 自動追尾シーケンス

自動追尾を行っているとき, 追尾範囲を越えたり, 飛 行機のバンクが大きくなると自動追尾状態から外れる ことがある. そのときも同じ一連の動作で追尾状態へと 導入する.

6.2 大阪ドーム飛行実験結果 実験では小型飛行機 をドーム内で $50 \mathrm{~m}$ 上空, 半径 $10 \mathrm{~m}$ で旋回運動させた(第 11 図).小型無人飛行機は 10 分間だけ飛行することが できるバッテリーを搭載してバッテリーのみで上空ま で上昇，レーザーシステムはこれを捕らえ，レーザー照 射による長時間飛行を行う, というデモンストレーショ ンを行った（第 12,13 図）.

追尾は約 1 時間ほど行い, バッテリー限界の 10 分を はるかに超える時間を無着陸飛行させることに成功し，

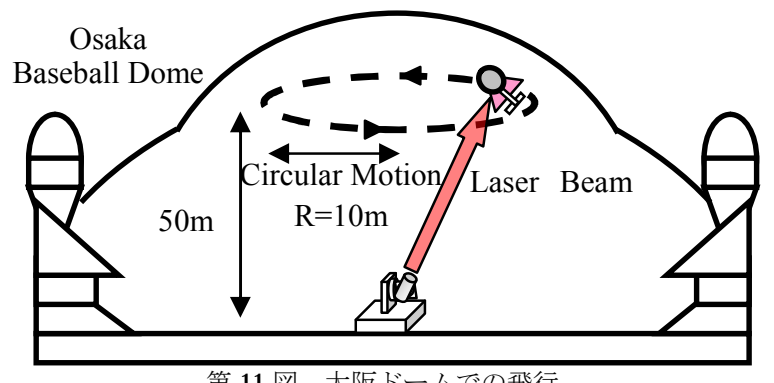

第 11 図 大阪ドームでの飛行

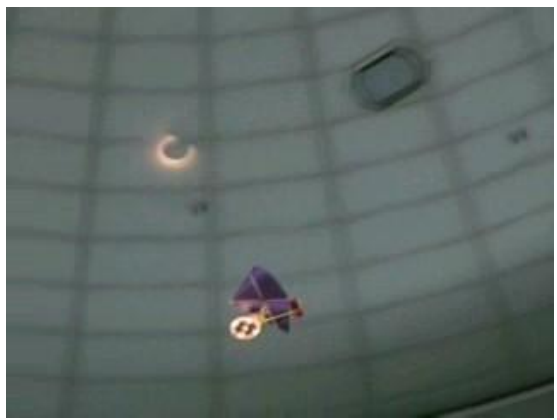

第 12 図 追尾中の様子（下からレーザーが照射され，ドー ム天井に太陽電池パネルと翼の影が見えている) 


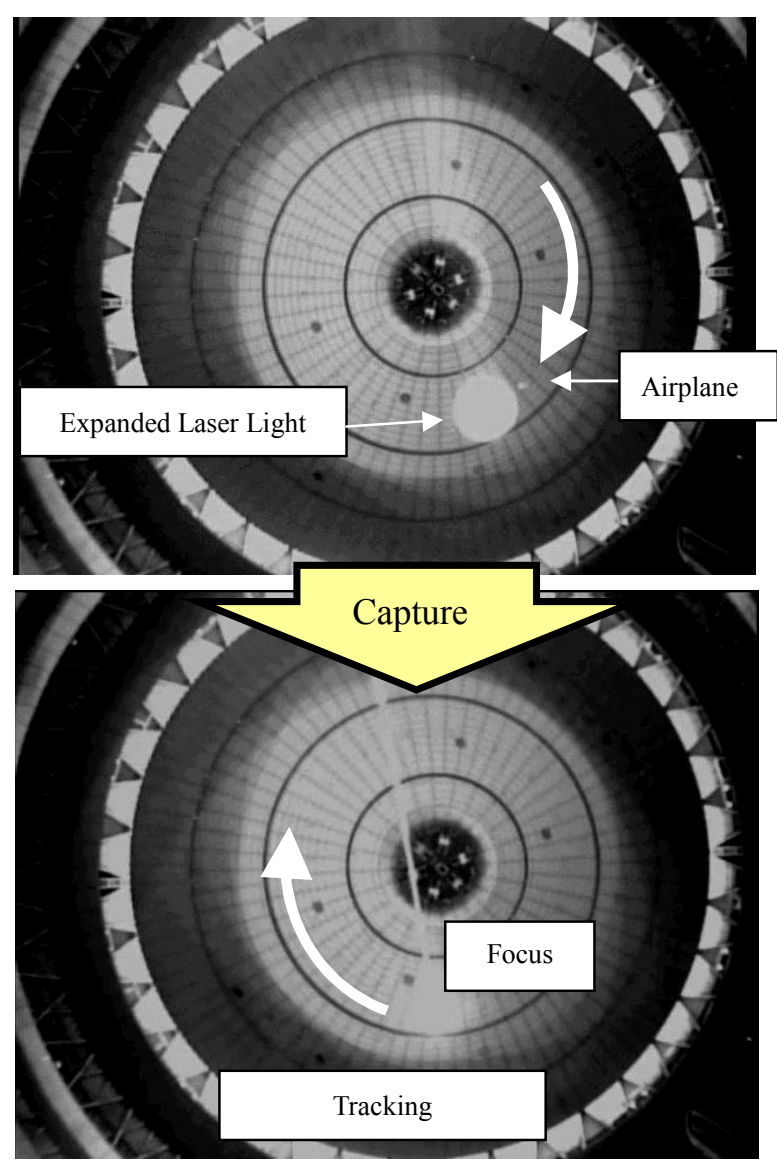

第 13 図 キャプチャー時の大阪ドーム天井を見上げた赤外線写真

レーザーのエネルギーのみで長時間飛行し続けること を実証できた. 飛行中は地上からレーザー距離計で飛行 高度を計測し，高度が 45〜 50 m を維持するように制御 した。この間の飛行距離はおよそ $18 \mathrm{~km}$ に達し, 平均飛 行速度はおよそ $5 \mathrm{~m} / \mathrm{s}$ であった（第 5 表）.

\begin{tabular}{|c|c|}
\hline 飛行高度 & $45 \sim 50 \mathrm{~m}$ \\
\hline 飛行時間 & 約 1 時間 \\
\hline 飛行距離 & 約 $18 \mathrm{~km}$ \\
\hline 平均飛行速度 & 約 $5 \mathrm{~m} / \mathrm{s}$ \\
\hline
\end{tabular}

\section{7. ヘリコプターヘのエネルギー伝送}

現在我々は 4 ローター式ヘリコプターへの自動追尾 によるレーザーエネルギー伝送を考えている (第 14 図). 太陽電池パネルはヘリコプターの上部か下部に取り付 ける. ヘリコプターは旋回運動することなく, 機体の向 きを変えることで太陽電池パネルをレーザーシステム へ向けることができる. また, ホバリングでの滞空, あ るいは観測したい場所へ搭載したカメラを見ながらゆ っくりと近づけるなどのオペレートが可能である. 太陽 電池は温度が上昇すると変換効率が低下寸るが, 飛行機 の場合，旋回運動時に風による空冷効果が期待できた。 ヘリコプターの場合旋回運動を行わないが，ローターが
常に回転して風がおこるので, その風を利用して太陽電 池パネルを冷却することになる。

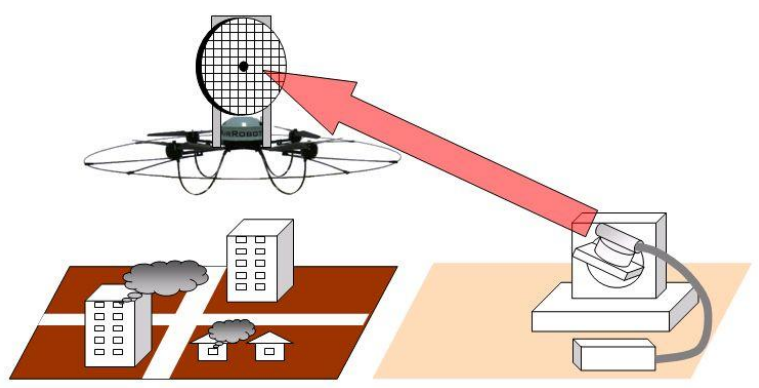

第14図 被災地でのへリコプターへのレーザーエネルギー伝送

7.14 ローターヘリコプター 我々はドイツの AirRobot 社が開発した 4 ローター方式のヘリコプター を使用することにした（第 6 表，第 15 図）。この機体は 中央に太陽電池パネルを搭載できるスペースがあり, 初 心者でも簡単に姿勢を安定させることが可能である.

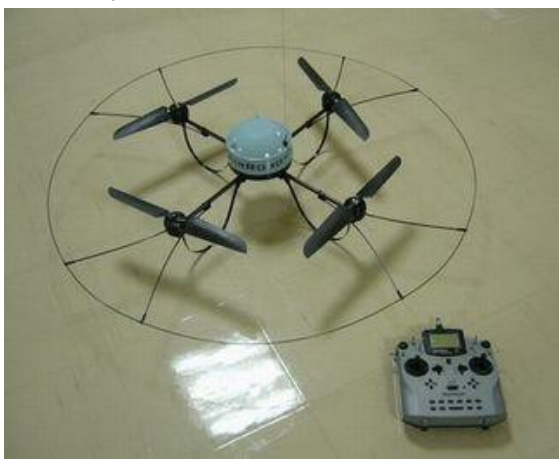

第 15 図 4 ローターヘリコプター

第 6 表 ヘリコプターの概要

\begin{tabular}{ll} 
サイズ & 直径 $1 \mathrm{~m}$ (防護バー直径) \\
重量 & $1 \mathrm{~kg}$ 以下 \\
搭載重量 & $200 \mathrm{~g}$ \\
ローター & ブラシレスモーター×4 機 \\
定格電圧 & $14.8 \mathrm{~V}$ \\
消費電力 & $93 \mathrm{~W}$ 以下（浮上 : 約 $90 \mathrm{~W})$ \\
飛行可能風速 & $4 \mathrm{~m} / \mathrm{s}$ \\
\hline
\end{tabular}

7.2 太陽電池パネルの高出力化 小型無人飛行機で 使用した太陽電池パネルは第 3 図のようにセルの貼ら れていない余白部分がある。また 30 枚の太陽電池セル を 10 枚ずつ直列に接続し， 3 本の直列を並列接続して いるが，重量をなるべく軽くするため, 極力配線を使用 しない接続方法を採用していた。

この余白に太陽電池を貼り付け, レーザーの強度分布 に合わせた太陽電池セルの接続方法を採用することで, 太陽電池パネルの変換効率をアップさせることができ ると考えられる.

そこで我々は太陽電池セルをおよそ半分にカットし， なるべく余白を埋めるように貼り付け, 高集積化した太 陽電池パネルを製作した.レーザー光強度はパネルの中 
心ほど高く, 直列に接続したセルの途中に暗いセルが来 ると電流に制限がかかるため, セルの接続は，セル上で のレーザー光強度の高いセル同士, 低いセル同士を直列 に接続し，接続方法でも効率アップを図った。
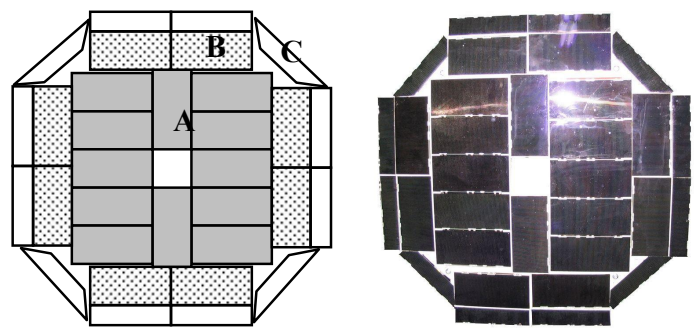

第 16 図高集積化太陽電池パネル

第 7 表 高集積化太陽電池パネルの概要

\begin{tabular}{ll}
\hline サイズ & 直径 : 約 $265 \mathrm{~mm}$ \\
重量 & 約 $80 \mathrm{~g}$ \\
太陽電池 & SingleJunction-GaAs 太陽電池 \\
& ノーマルサイズ $(30 \mathrm{~mm} \times 64.5 \mathrm{~mm}): 20$ 枚 \\
& ハーフカットサイズ $(15 \mathrm{~mm} \times 64.5 \mathrm{~mm}): 12$ 枚 \\
& $\quad$ (長方形 8 枚 台形 4 枚 $)$
\end{tabular}

(長方形 8 枚,台形 4 枚)

太陽電池セルは第 16 図左の $\mathrm{A}$ が 12 枚直列, $\mathrm{B}$ が 8 枚 直列, C が 12 枚直列（カットセルのみ使用）で接続し， $\mathrm{B}$ 列と $\mathrm{C}$ 列を並列に接続した後, $\mathrm{A}$ 列と直列に接続した

（電圧は小型バッテリーに合わせている）。この高集積 化太陽電池パネルに向けて半導体レーザーを $60 \mathrm{~cm}$ 離 れたところから照射, C 列が含まれる場合と含まれない 場合の出力を計測した.

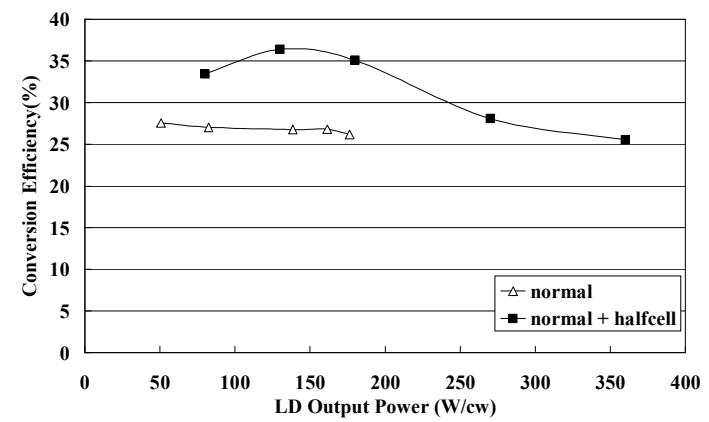

第 17 図 カット太陽電池セルの取付け有無による太陽 電池パネルの变換効率の比較

第 8 表 高集積化太陽電池パネル出力

\begin{tabular}{cccc}
\hline \multirow{2}{*}{$\begin{array}{c}\text { LD 出力 } \\
(\mathrm{W} / \mathrm{cw})\end{array}$} & \multicolumn{3}{c}{ 太陽電池パネル } \\
\cline { 2 - 4 } 電压 $(\mathrm{V})$ & 電流(A) & 出力 $(\mathrm{W})$ \\
\hline 80 & 17.04 & 1.57 & 26.75 \\
130 & 16.15 & 2.93 & 47.31 \\
180 & 16.07 & 3.93 & 63.15 \\
270 & 15.8 & 4.8 & 75.84 \\
360 & 15.6 & 5.9 & 92.04 \\
\hline
\end{tabular}

その結果，第 16 図のように余白にカットしたセルを 貼り付けることで太陽電池パネルとしての変換効率を アップさせることに成功した．

また, 第 17 図における半導体レーザー出力 $360 \mathrm{~W} / \mathrm{cw}$ での太陽電池パネル出力は第 8 表の通り約 $92 \mathrm{~W}$ となり, 飛行に必要な $90 \mathrm{~W}$ 以上の出力を得ることができた.

この高集積化太陽電池パネルを使用してヘリコプター に接続したところ，浮上することに成功した.

\section{8. 課題と今後の発展}

小型飛行機の飛行実験はレーザーエネルギー伝送によ る長時間飛行に成功したが，この飛行機は完全に手動制 御であるため, 長時間飛行には操縦者の負担がかなり大 きいという問題があった. 実用化のためには定位置で旋 回飛行を行えるような自立飛行機能を組み込むことが 不可欠である. 最近の小型化された GPS モジュールの 利用が考えられる.この他, 太陽電池パネルの変換効率 アップや機体の飛行効率の向上により可搬重量を増や し, 地上観測機器の増設やバッテリー容量増加によって 無受光飛行時間を増やし, 飛行可能範囲を広げることな どの性能アップが考えられる.

ヘリコプターの実験はやっとレーザーエネルギーの みで浮上した状態である. 今後太陽電池パネルをへリコ プターに取り付けていくと機体重量が増えるという問 題がある. 今後は余裕のある飛行ができるようレーザー 光の増強, 機体の軽量化, 太陽電池パネルの取付け位置 による冷却効果の検討等を行っていく予定である.また， ヘリコプターの操縦技術を習得し, 離れた場所からのレ ーザーエネルギー伝送による長時間の自動追尾飛行実 験につなげていくつもりである.

\section{参 考 文 献}

1)武田和也，河島信樹：無人月水探査探査車（ローバー）モデルへ の $1.2 \mathrm{~km}$ レーザーエネルギー伝送実験, 宇宙技術，3(2004), pp.45-48.

2)Feldman, W. C., Maurice, S., Binder, A. B., Barraclough, B. L., Elphic, R. C., and Lawrence, D. J.: Fluxes of Fast and Epithermal Neutrons from Lunar Prospector, Evidence for Water Ice at the Lunar Poles, Science, 281(1998), pp.1496-1500.

3)Kawashima, N., and Takeda, K.: $1.2 \mathrm{~km}$ Laser Energy Transmission for the Development of a Lunar Rover Confirming the Presence of Ice on the Moon, Proceedings of ILC2003/ILEWG5, 108/2003, pp.291-294.

4)NASA：レーザーエネルギー伝送プロジェクト紹介のページ

(http://www.nasa.gov/centers/dryden/history/pastprojects/Beam/index.html) 5) Yabe, T., Phipps, C., Yamaguchi, M., Nakagawa, R., Aoki, K., Mine, H., Ogata, Y., Baasandash, C., Nakagawa, M., Fujiwara, E., Yoshida, K., Nishiguchi, A., and Kajiwara, I.: Microairplane Propelled by Laser Driven Exotic Target, Appl. Phys. Lett., 80(2002), pp.4318-4320.

6) Kawashima, N., Takeda, K., and Yabe, K.: Application of the Laser Energy Transmission Technology to Drive a Small Airplane, Proceedings of APLS2006, 5/2007,pp.S109-S110. 